\title{
Associations between mutations of the cell cycle checkpoint kinase 2 gene and gastric carcinogenesis
}

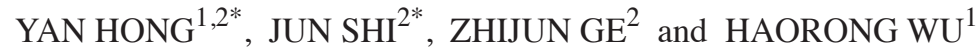 \\ ${ }^{1}$ Department of General Surgery, The Second Affiliated Hospital of Soochow University, Suzhou, Jiangsu 215004; \\ ${ }^{2}$ Department of General Surgery, Yixing People's Hospital, Yixing, Jiangsu 214200, P.R. China
}

Received May 5, 2016; Accepted May 18, 2017

DOI: $10.3892 / \mathrm{mmr} .2017 .7080$

\begin{abstract}
Gastric cancer is the most common malignant tumor of the digestive system. The etiology of gastric cancer is complex, and susceptibility at the genetic level remains to be fully elucidated in genetic investigations. In the present study, mutations of the cell cycle checkpoint kinase 2 (CHEK2) gene and its association with gastric cancer were examined. Reverse transcription-quantitative polymerase chain reaction technology was used to detect the expression of CHEK2 and it was found that the expression of CHEK 2 was low in gastric cancer. Using sequencing analysis, it was found that the low expression level of CHEK2 was associated with expression of its mutation. The present study also established a CHEK2-overexpressing mutant and confirmed that CHEK2 promoted gastric cancer cell proliferation. Overexpression of the CHEK2 mutation was confirmed to promote cancer cell migration and invasion. Furthermore, western blot analysis results revealed that overexpression of the CHEK2 mutation downregulated E-cadherin and upregulated vimentin expression, indicating the mechanism underlying the altered biological behavior. These results suggested that there was a correlation between mutation of the CHEK 2 gene and gastric cancer, and provided an experimental basis for antitumor drug investigation and development according to its mutation target.
\end{abstract}

\section{Introduction}

Gastric carcinoma is one of the fourth most common types of malignant tumor worldwide (1-3). As the most common type of malignant tumor of the digestive system, gastric cancer has been confirmed as the second leading cause of cancer-associated mortality worldwide from statistical data of mortality

Correspondence to: Dr Haorong Wu, Department of General Surgery, The Second Affiliated Hospital of Soochow University, 1055 Sanxiang Road, Suzhou, Jiangsu 215004, P.R. China

E-mail:wuhaorong6966@126.com

*Contributed equally

Key words: cell cycle checkpoint kinase 2, mutation, gastric cancer rates $(4,5)$. The etiology of gastric cancer is complex, involving various factors, including age, gender, socioeconomic status, state of health and environmental risk factors (6-8). All these factors occur in different stages, targeting different genes and regulatory factors, and causing changes in the structure and expression level of associated genes, eventually leading to the occurrence and development of gastric cancer due to the combination of these genes and regulatory factors (9-12). Surgery is a primary treatment option for gastric cancer, and is also the only option expected to cure this type of cancer (13). Due to a lack of characteristic clinical manifestations in early gastric cancer, diagnosis is difficult, therefore, the majority of patients have already developed advanced gastric cancer, which is passed the optimal stage for surgery $(14,15)$. The treatment efficacy for advanced gastric carcinoma is poor and the overall prognosis is poor. Therefore, identifying molecular diagnostic indices and effective therapeutic targets at the tumor gene level have become a novel area of interest in gastric cancer.

Cell cycle checkpoint kinase 2 (CHEK2) has been identified as a type of serine/threonine protein kinase, located in chromosome 22 q12.1 of humans and yeast. It has been confirmed as an important mediator of the DNA damage response pathway, and as a susceptibility gene in several types of cancer $(16,17)$. As a tumor suppressor gene, CHEK2 is vital for the induction of cell cycle arrest and cell apoptosis following DNA damage. When CHEK2 mutation occurs, the coding kinase is inactivated and the damaged DNA cannot repair, following which abnormal DNA replicates uncontrollably, leading to the cancer $(18,19)$. As primary forms of mutations in the malignant tumor, missense mutations and truncated mutants lead to a significant decrease or even the complete loss of CHEK2 kinase activity $(20,21)$. For CHEK2, the four gene mutation sites, 1100delc, IVS2G>A, del5395 and 1157T, have been identified (22). Among these, 1100delc, IVS2G $>$ A and del5395 are truncated mutations, which can lead to the truncation of premature proteins. $1157 \mathrm{~T}$ is a missense mutation, consisting of an isoleucine for threonine replacement (23).

Previous studies have found that the CHEK2 gene is a multi-tumor susceptibility gene. In patients with breast cancer, prostate cancer, colon cancer and other types of malignant tumor, low frequency mutations were found in embryonic and somatic cells $(24,25)$. In addition, mutation carriers are at increased risk of breast cancer, thyroid cancer, bladder cancer, ovarian cancer and colorectal cancer $(26,27)$. Mutations in 
CHEK2 have been associated with cancer at several sites; CHEK2 mutations have been reported to predispose to gastric cancer, particularly to young-onset cases (28). At present, the specific role of the CHEK2 gene in gastric cancer and its mechanism remain to be fully elucidated, and the association between CHEK2 and gastric cancer requires extensive investigation.

In the present study, patients with gastric cancer and healthy individuals were assessed for gene mutations using polymerase chain reaction (PCR) analysis combined with a gene sequencing assay, in order to investigate the association between the CHEK2 gene and gastric cancer. The results confirmed that the expression of CHEK2 was low in gastric cancer and the low expression of CHEK2 was closely associated with expression of its mutation. Detailed investigations were performed on the mechanism of CHEK2 mutation, providing an experimental basis for the development of anticancer drugs contraposing its mutation targets.

\section{Materials and methods}

Collection of gastric cancer data. The collection and sorting of clinical data was performed for a total of 105 cases of gastric carcinoma using conventional paraffin-embedded tissue samples and fresh specimens from surgery between May 2013 and June 2014 at the Second Affiliated Hospital of Soochow University (Suzhou, China). Of the patients recruited, 63 were men, 42 were women and all were aged between 30 and 82 years (median, 62 years). None of the patients had received preoperative cancer treatment. All cases were diagnosed as gastric adenocarcinoma using conventional hematoxylin and eosin staining, which comprised 6 cases with well differentiated carcinoma, 25 cases of moderately differentiated carcinoma and 74 cases of poorly differentiated carcinoma. In addition, 62 cases exhibited lymph node metastases, whereas 43 cases showed no lymph node metastasis. No cases exhibited distant metastases. According to the Union for International Cancer Control installment standard P-TNM classification (revised in 1997) (29), of the 105 cases, there were: 2 cases in stage 0 , 24 cases in stage I, 42 cases in stage II, 31 cases in stage III and 6 cases in stage IV. From all cases, normal gastric tissue was obtained from $5 \mathrm{~cm}$ away from the stomach tissue tumor lesions as negative control. The present study was approved by the ethics committee of the Second Affiliated Hospital of Soochow University. Written informed consent was obtained from all patients.

Blood samples and genotyping. The fresh blood samples from each individual were anticoagulated with $3.8 \%$ sodium citrate, and cells from each sample were isolated by centrifugation $\left(400 \mathrm{x} \mathrm{g}\right.$ for $30 \mathrm{~min}$ at $22^{\circ} \mathrm{C}$ ) and frozen at $-80^{\circ} \mathrm{C}$ until use. The DNA extraction kit and paraffin-embedded tissue DNA extraction kit were from Tiangen Biotech Co., Ltd. (Beijing, China). The TaqMan MGB probe (Invitrogen; Thermo Fisher Scientific, Inc., Waltham, MA, USA) and primers were used for rs2236142 genotyping. Primer pairs were as follows: 1100delc forward, 5'-GCA AAA TTA AAT GTC CTA ACT TGC-3' and reverse, 5'-CCA GTC TGT GCA GCA ATG AA-3'; IVS2G>A forward, 5'-CTA CTG GTT TGG GAG GGA CA-3' and reverse, 5'-GA CCA AAT TAC CAG CTC TCC-3'; Del5395 forward, 5'-AGG TGC AGC ATC CTG TTC G-3' and reverse, 5'-AGG ATT GCT CCC AAT CAC TG-3'; 1157T forward, 5'-TTT CGG ATT TTC AGG GTA GG-3' and reverse, 5'-ATT CAA AGG ACG GCG TTT TC-3'. The PCR amplification procedure was as follows: Initial denaturation at $95^{\circ} \mathrm{C}, 2 \mathrm{~min}$; 33 cycles of $95^{\circ} \mathrm{C}$ for $30 \mathrm{sec}, 58^{\circ} \mathrm{C}$ for $30 \mathrm{sec}, 72^{\circ} \mathrm{C}$ for $1 \mathrm{~min}$. The genotyping experiments were repeated for $15 \%$ of the sample and the results were $100 \%$ consistent.

Cell culture. Normal gastric mucosa cells (GES1), and the gastric cancer cell lines BGC-823, SGC7901 and AGS were purchased from the Shanghai Cell Bank of the Chinese Academy of Sciences. The cells were cultured in $10 \%$ fetal bovine serum and penicillin/streptomycin DMEM medium (both from Gibco; Thermo Fisher Scientific, Inc.) in an incubator at $37^{\circ} \mathrm{C}$ and $5 \% \mathrm{CO}_{2}$.

RNA isolation and cDNA generation. Total RNA from the gastric tissues and cell lines were isolated using a miRNA isolation kit (Ambion; Thermo Fisher Scientific, Inc.) according to the manufacturer's protocol. cDNA was generated using the stem-loop reverse transcript primer and Moloney murine leukemia virus reverse transcriptase (Promega Corporation, Madison, WI, USA). RT-qPCR was performed on the QuantStudio 6 Flex Realtime PCR system (Applied Biosystems; Thermo Fisher Scientific, Inc.). The cycling parameters were as follows: $2 \mathrm{~min}$ at $95^{\circ} \mathrm{C}$, followed by 45 cycles of $10 \mathrm{sec}$ at $95^{\circ} \mathrm{C}$ and $60 \mathrm{sec}$ at $60^{\circ} \mathrm{C}$. The following primers were used: CHEK2 forward, 5'-CCC TCC CAA ACC AGT AGT TGT-3' and reverse, 5'-ACA GCC CCA TGG CAG CG-3'; GAPDH forward, 5'-GAG TCC ACT GGC GTC TTC-3, reverse, 5'-GTG CTA AGC AGT TGG T-3'. Human GAPDH served as an internal control. Data were analyzed with the $2^{-\Delta \Delta \mathrm{Cq}}$ method (30).

Plasmid construction. For CHEK2 overexpression, the complete coding sequence of mutated CHEK2 (1100delc) was cloned into a pcDNA3 vector (Thermo Fisher Scientific, Inc.) to form the vector pCHEK2-Mut. The blank vector served as a control. Transfection was performed in 24-well plates ( $2 \times 10^{5}$ BGC-823 or SGC7901 cells in each well) with Lipofectamine 2000 (Invitrogen; Thermo Fisher Scientific, Inc.) according to the manufacturer's protocol. At $48 \mathrm{~h}$ after transfection, the cells were used in the following experiments.

MTT assay. For the MTT assay, BGC-823 and SGC7901 cells $\left(1 \times 10^{5}\right)$ were seeded into 96-well plates, and transfected with pCHEK2-Mut or the negative control (blank pcDNA3) for $48 \mathrm{~h}$. At 24, 48 and $72 \mathrm{~h}$ post-transfection, $10 \mu \mathrm{l}$ MTT $(0.5 \mathrm{mg} / \mathrm{ml}$; Sigma-Aldrich; Merck KGaA, Darmstadt, Germany) was added to the culture solution. The cells were incubated at $37^{\circ} \mathrm{C}$ for $4 \mathrm{~h}$ and the medium was removed. To dissolve the formazan, $100 \mu 1$ DMSO (Sigma-Aldrich; Merck KGaA) was added, and a Quant universal microplate spectrophotometer (BioTek Instruments, Inc., Winooski, VT, USA) was used to observe the absorbance at $570 \mathrm{~nm}$ (A570).

Cell proliferation assay. Cell proliferation was assessed using the colony formation experiment. Following transfection with pCHEK2-Mut or pcDNA3 as aforementioned, a total 
Table I. Genotype analysis in gastric cancer tissue and blood samples.

\begin{tabular}{lccccc}
\hline & & \multicolumn{4}{c}{ Genotype } \\
\cline { 3 - 6 } Gastric cancer sample & $\mathrm{n}$ & 1100delc (\%) & IVS2G>A (\%) & Del5395 (\%) & $1157 \mathrm{~T}(\%)$ \\
\hline Tissue & 105 & $5(4.7)$ & $2(1.9)$ & $0(0)$ & $1(0.9)$ \\
Blood & 105 & $3(2.8)$ & $1(0.9)$ & $1(0.9)$ & $0(0)$ \\
\hline
\end{tabular}

of 200 cells in the logarithmic phase were seeded in $6-\mathrm{cm}$ culture dishes with culture medium, and the plates were incubated in a humidified atmosphere at $37^{\circ} \mathrm{C}$ for 2 weeks. When microscopic colonies were observed, the culture medium was discarded and the cells were washed gently twice with PBS, fixed in 4\% paraformaldehyde for $15 \mathrm{~min}$ and stained in Giemsa (Sigma-Aldrich; Merck KGaA) for $20 \mathrm{~min}$ at room temperature. The cells were air-dried, and the colony number of each group was counted under an optical microscope. The experiment was repeated three times.

Migration and invasion assay. At $48 \mathrm{~h}$ following pCHEK2-Mut or pcDNA3 transfection, the cells were used for a Transwell assay. For cell invasion analysis, a Transwell chamber with an $8.0-\mu \mathrm{m}$ pore polycarbonate filter insert pre-coated with Matrigel was used. Cells $\left(5 \times 10^{4}\right)$ were suspended in $200 \mu 1$ serum-free medium and the cell suspension was seeded in the upper chamber. The lower chamber was filled with $600 \mu \mathrm{l}$ normal culture medium. The 24-well plates were incubated at $37^{\circ} \mathrm{C}$ for $48 \mathrm{~h}$, and non-traversed cells were subsequently wiped away with a cotton swab. Traversed cells on the lower side were stained with crystal violet for $20 \mathrm{~min}$, and counted under an optical microscope (BH-2; Olympus Corporation, Tokyo, Japan). For cell migration analyses, the same procedures were performed without the use of Matrigel.

Western blot. Protein samples of cells were extracted using radioimmunoprecipitation assay lysis buffer (Beyotime Institute of Biotechnology, Haimen, China) and quantified using a bicinchoninic acid protein assay. The protein samples (0.1 mg) were separated by $10-12 \%$ SDS-PAGE and transferred to a polyvinylidene fluoride membrane. The blot was blocked in 5\% skimmed milk for $2 \mathrm{~h}$ at room temperature and subsequently incubated with the primary antibodies at $4^{\circ} \mathrm{C}$ overnight for the detection of: E-cadherin (1:1,000; ab76055) and vimentin (1:1,000; ab8978) (both from Abcam, Cambridge, UK). GAPDH (1:5,000; ab8245; Abcam) served as an internal control. The membrane was subsequently incubated with the anti-mouse horseradish peroxidase-conjugated IgG secondary antibody (1:5,000; ab131368) at room temperature for $1 \mathrm{~h}$. The positive bands were visualized by Plus Western Blotting Substrate (Pierce; Thermo Fisher Scientific, Inc.), and the grey level of bands was analyzed using Image 1.49 (National Institutes of Health, Bethesda, MD).

Statistical analysis. The data were presented as the mean \pm standard deviation of at least three independent experiments. Student's t-test (two-tailed) was used. $\mathrm{P}<0.05$ value was considered to indicate a statistically significant difference.
Statistical analyses were performed using Graphpad 6.0 (GraphPad Software Inc., San Diego, CA).

\section{Results}

CHEK2 is expressed at low levels in gastric cancer tissues and gastric cancer cells. The present study detected the mRNA expression level of CHEK2 in 105 pairs of gastric cancer tissue specimens and normal adjacent tissues using RT-qPCR analysis. The results showed that the expression of CHEK2 in the gastric cancer group was significantly lower, compared with that in than normal group (Fig. 1A). Subsequently, the present study detected the mRNA expression level of CHEK2 in normal gastric mucosa cells (GES-1), and in BGC-823, SGC7901 and AGS gastric cancer cells using RT-qPCR analysis (Fig. 1B). The results were consistent with the results obtained in the tissue assays above. All these results suggest that CHEK2 was expressed at low levels in gastric cancer tissues and gastric cancer cells.

CHEK2 mutation is present in patients with gastric cancer. It has been shown that the genetic susceptibility of several types of malignant tumor is associated with CHEK2 gene mutations, including gastric cancer, breast cancer and prostate cancer $(28,31,32)$. Whether the low expression of CHEK2 in gastric cancer is associated with its mutations required detailed investigation. In the present study, RNA was extracted from tissue samples and serum of from 105 cases of gastric cancer. The RNA was then reversed transcribed into cDNA for sequence alignment of the expression of CHEK2. The results (Table I) showed that the CHEK2 mutation was present in patients with gastric cancer, with 1100delc and IVS2G>A being the two predominant mutation forms.

CHEK2 (1100delc) promotes proliferation of gastric cancer cells. The present study subsequently examined the effects of mutant CHEK2 (1100delc) on gastric cancer cell vitality. The CHEK2 (1100delc) mutation plasmid, pCHEK2-Mut, was first constructed, and pCHEK2-Mut was transfected into the BGC-823 and SGC7901 gastric cancer cell lines. The effects of the mutant on gastric malignant proliferation were determined using MTT and clone formation assays. As shown in Fig. 2, the CHEK2 (1100delc) mutation promoted the proliferation and clone formation of the gastric cancer cells. In conclusion, the mutant CHEK2 (1100delc) promoted malignant gastric cancer cell proliferation.

CHEK2 (1100delc) promotes gastric cancer cell migration and invasion. In the subsequent experiments, Transwell 

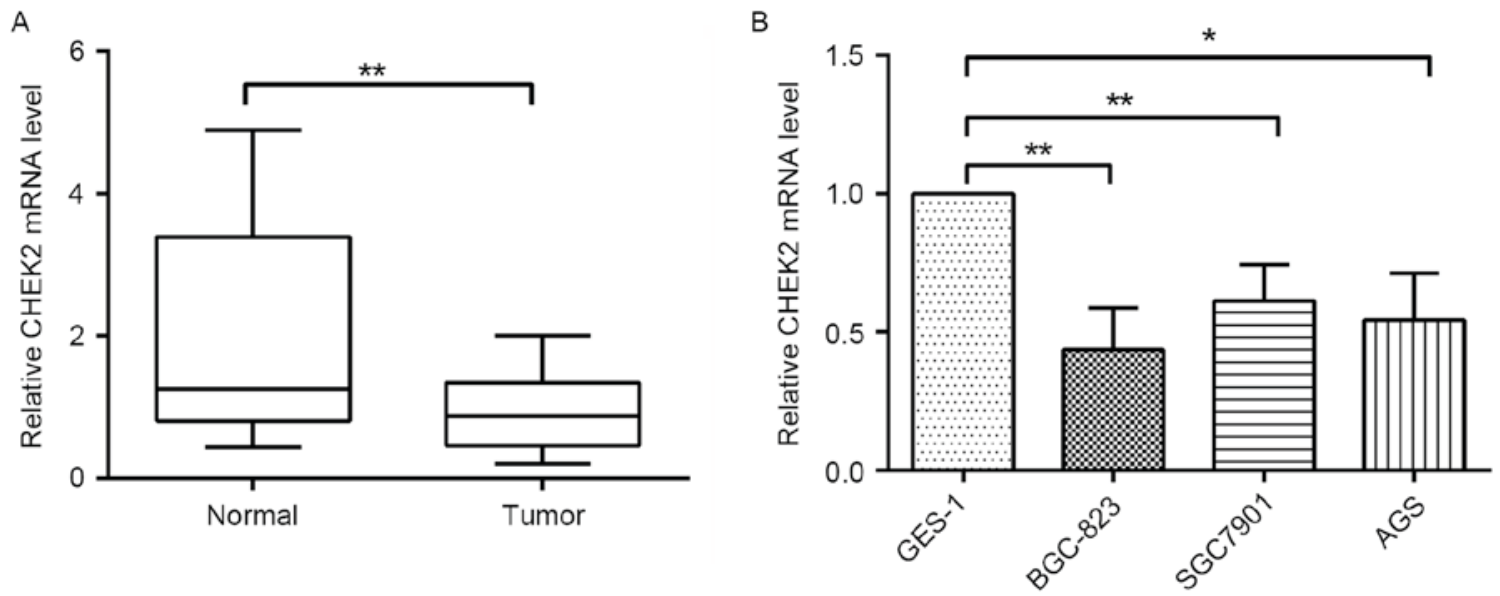

Figure 1. mRNA expression levels of CHEK2. The relative mRNA expression level of CHEK2 in (A) normal tissues, gastric tumor tissues, and (B) gastric cancer cells were detected using reverse transcription-quantitative polymerase chain reaction analysis. ${ }^{*} \mathrm{P}<0.05$ and ${ }^{* *} \mathrm{P}<0.01$. CHEK2, cell cycle checkpoint kinase 2 .

A
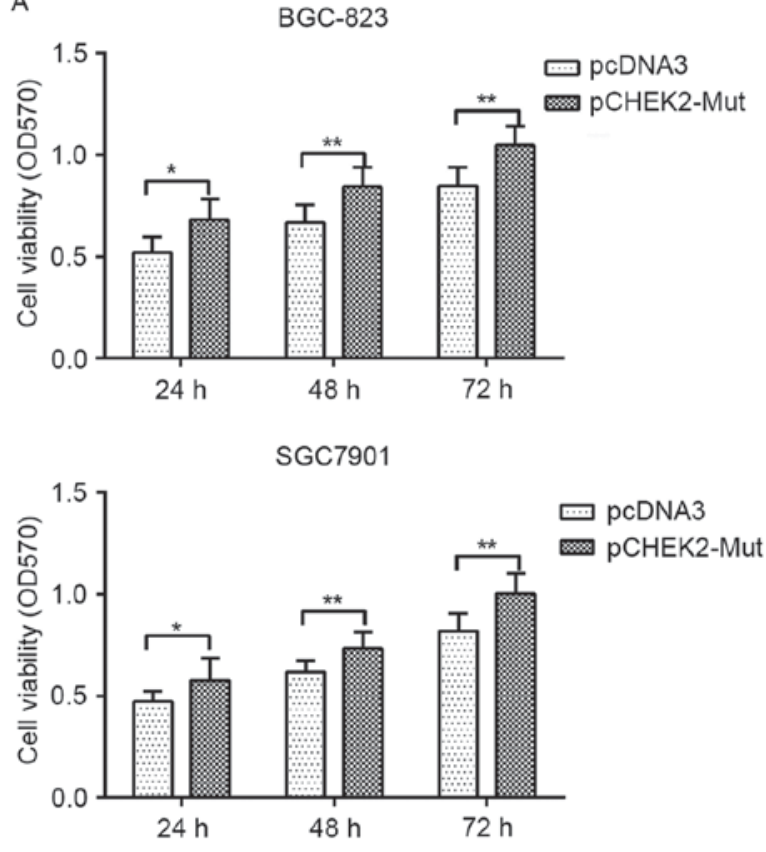

B

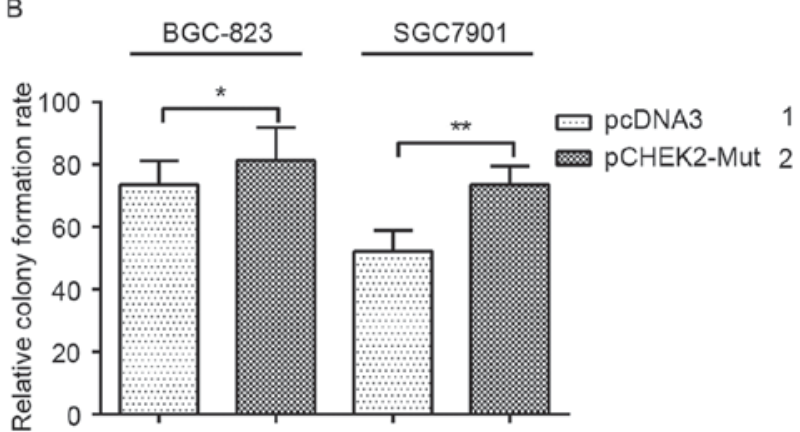

Figure 2 Effects of CHEK2 (1100delc) on gastric cancer cell proliferation. (A) Cell viability and (B) proliferation were respectively detected by 3-(4,5-dimethylthiazol-2-yl)-2,5-diphenyl-tetrazolium bromide and colony formation assays ${ }^{*} \mathrm{P}<0.05$ and ${ }^{* *} \mathrm{P}<0.01$. CHEK2, cell cycle checkpoint kinase 2; mut, mutant.

migration and invasion experiments were performed to examine the effects of mutant CHEK2 on gastric cancer
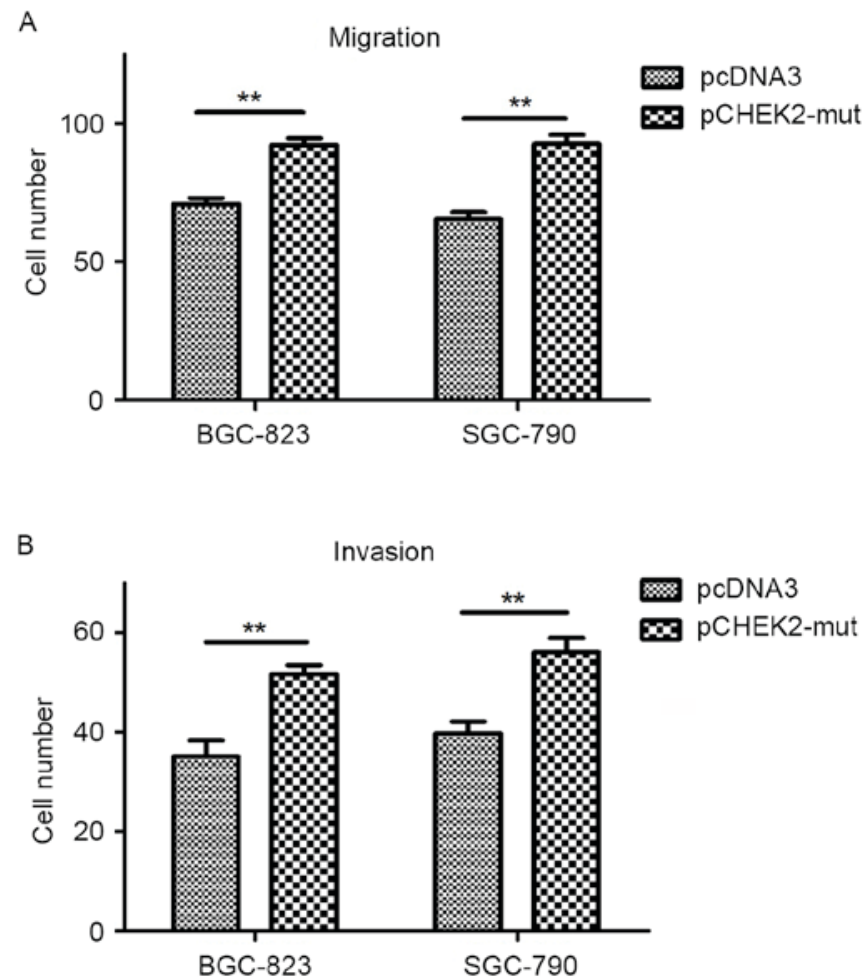

Figure 3. Effects of mutant (1100delc) on gastric cancer cell migration and invasion. (A) Migration and (B) invasion of BGC-823 and SGC-790 gastric cancer cells are shown. ${ }^{* *} \mathrm{P}<0.01$. CHEK2, cell cycle checkpoint kinase 2; mut, mutant.

cell migration and invasion. The results, as shown in Fig. 3, showed that transfection of BGC-823 and SGC-7901 gastric cancer cells with pCHEK2-Mut promoted the cell migration and invasion abilities.

Molecular mechanism of CHEK2 (1100delc) on gastric cancer. Based on the results described above, the present study examined the expression of tumor metastasis related proteins in BGC-823 and SGC-790 cells. Western blot analysis (Fig. 4) indicated that mutant CHEK2 (1100delc) downregulated E-cadherin expression, and upregulated vimentin expression. 


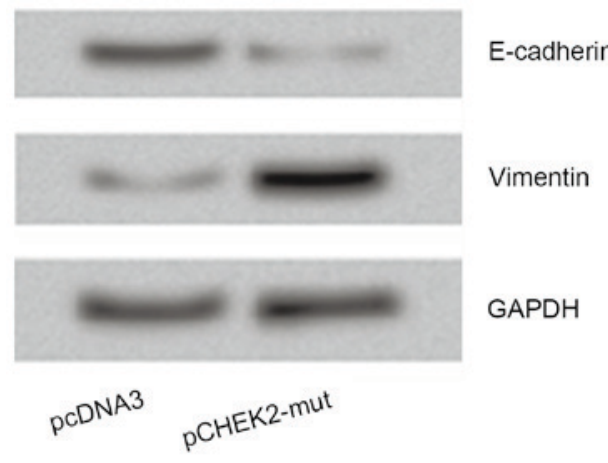

Figure 4. Epithelial-mesenchymal transition and cell cycle of gastric cancer cells. The expression of E-cadherin and vimentin in BGC-823 gastric cancer cell was detected by western blot analysis. CHEK2, cell cycle checkpoint kinase 2; mut, mutant.

\section{Discussion}

CHEK2 is a type of serine/threonine protein kinase, located in chromosome 22 q12.1 of humans and yeast, and has been reported to encode for a G2 checkpoint kinase, which is critical in DNA repair $(32,33)$. As an important signal transducer of cellular responses to DNA damage, and a candidate tumor suppressor contributing to molecular pathogenesis of several types of human malignancy, germline mutations in CHEK2 (1100delC, IVS2+1G >A and I157T) have been confirmed to be associated with several types of cancer $(34,35)$. Its mutation confers an increased risk of sporadic and hereditary disease, including breast cancer and prostate cancer $(36,37)$.

CHEK2 is involved in DNA damage repair and protects the integrity of the genome. The reaction pathway is activated following DNA damage, leading to stagnation of the cell cycle, providing time for damage repair, and inducing gene transcription to facilitate repair at the same time (38). If DNA damage is unable to repair, the damaged cell can initiate apoptosis, and CHEK2 kinase may be involved in the DNA damage caused by cell apoptosis (39). Defects of the DNA damage response pathway leads to genomic instability and cancer susceptibility. In the study by Stolz et al, the CHEK2 gene was confirmed as being necessary in maintaining chromosomal stability in the process of mitosis, although this action was not associated with DNA damage (40). The abnormal CHEK2-mediated phosphorylation of BRCA1 can lead spindle assembly errors in the $\mathrm{M}$ phase of mitosis, thus inducing human cell chromosome instability, which is an important characteristic of tumor cells, and is important in the processes of tumor occurrence and development (41). Previous studies have shown that CHEK2 mutations predispose to gastric cancer, particularly young-onset cases (28), however, the association between CHEK 2 and gastric cancer, and the underlying molecular mechanism require extensive investigation.

The present study preliminary discussed the role of CHEK2 in gastric cancer, and it was found that the expression of CHEK2 was low in gastric cancer tissues and gastric cancer cells using RT-qPCR analysis. In the following experiments, this was found to be due to mutation by examining 105 cases of gastric cancer tissues and serum RNA samples. Furthermore, the CHEK2 mutant was found to promote cell proliferation, migration and invasion in malignant gastric cancer.
Epithelial-mesenchymal transition (EMT) is a carcinogenesis-enabling process, and is important in the initiation of invasion and metastasis. N-cadherin is an EMT marker positively associated with the metastasis of tumor cells, whereas E-cadherin is a negative correlation marker (42). It is governed by several signal transduction pathways, which culminate in core transcription factors of the process (43). On investigating the mechanism of CHEK2 in gastric cancer, the present study demonstrated that mutant CHEK2 (1100delc) downregulated E-cadherin expression and upregulated vimentin expression, indicating the mutant CHEK2 (1100delc) promoted gastric cancer cell migration and invasion through regulation of EMT-related proteins.

Taken together, the observations in the present study revealed novel roles of CHEK2 in gastric cancer, provided novel information regarding molecular genetics and assisted in clarifying the pathogenesis, suggesting it is a potential target for developing therapeutics against gastric cancer. Specific elements of the follow-up mechanism in animal models and the signaling pathway require further validation through experiments.

\section{References}

1. Zhang H, Duan J, Qu Y, Deng T, Liu R, Zhang L, Bai M, Li J Ning T, Ge $S$, et al: Onco-miR-24 regulates cell growth and apoptosis by targeting BCL2L11 in gastric cancer. Protein Cell 7: 141-151, 2016.

2. Jian B, Li Z, Xiao D, He G, Bai L and Yang Q: Downregulation of microRNA-193-3p inhibits tumor proliferation migration and chemoresistance in human gastric cancer by regulating PTEN gene. Tumour Biol 37: 8941-8949, 2016.

3. Wang Z, Zhang X, Hu J, Zeng W, Liang J, Zhou H and Zhou Z: Predictive factors for lymph node metastasis in early gastric cancer with signet ring cell histology and their impact on the surgical strategy: Analysis of single institutional experience. J Surg Res 191: 130-133, 2014.

4. Cheng LL, Itahana Y, Lei ZD, Chia NY, Wu Y, Yu Y, Zhang SL, Thike AA, Pandey A, Rozen S, et al: TP53 genomic status regulates sensitivity of gastric cancer cells to the histone methylation inhibitor 3-deazaneplanocin A (DZNep). Clin Cancer Res 18: 4201-4212, 2012.

5. Liu H, Zhu L, Liu B, Yang L, Meng X, Zhang W, Ma Y and Xiao H: Genome-wide microRNA profiles identify miR-378 as a serum biomarker for early detection of gastric cancer. Cancer Lett 316: 196-203, 2012.

6. Aoyama T, Hayashi T, Fujikawa H, Ogata T, Cho H, Wada H, Kitani Y, Yukawa N, Oshima T, Rino Y, et al: Effect of enteral nutrition enriched with eicosapentaenoic acid on body weight loss and compliance with S-1 adjuvant chemotherapy after gastric cancer surgery. Gan To Kagaku Ryoho 40: 2289-2291, 2013 (In Japanese).

7. Mirmajidi SH, Najafi M, Mirmajidi ST and Nasri Nasrabadi N: Study of regulatory promoter polymorphism $(-248 \mathrm{G}>\mathrm{A})$ of Bax gene in patients with gastric cancer in the northern provinces of Iran. Gastroenterol Hepatol Bed Bench 9: 36-44, 2016.

8. Yang I, Woltemate S, Piazuelo MB, Bravo LE, Yepez MC, Romero-Gallo J, Delgado AG, Wilson KT, Peek RM, Correa P, et al: Different gastric microbiota compositions in two human populations with high and low gastric cancer risk in Colombia. Scientific Rep 6: 18594, 2016

9. Loh JT, Shaffer CL, Piazuelo MB, Bravo LE, McClain MS, Correa P and Cover TL: Analysis of cagA in Helicobacter pylori strains from Colombian populations with contrasting gastric cancer risk reveals a biomarker for disease severity. Cancer Epidemiol Biomarkers Prev 20: 2237-2249, 2011

10. Chen J, Dong S, Hu J, Duan B, Yao J, Zhang R, Zhou H, Sheng H, Gao H, Li S and Zhang X: Guanine nucleotide binding protein-like 3 is a potential prognosis indicator of gastric cancer. Int J Clin Exp Pathol 8: 13273-13278, 2015.

11. Li YF, Wang DD, Zhao BW, Wang W, Huang CY, Chen YM, Zheng Y, Keshari RP, Xia JC and Zhou ZW: High level of COP1 expression is associated with poor prognosis in primary gastric cancer. Int J Biol Sci 8: 1168-1177, 2012. 
12. Tsukamoto Y, Fumoto S, Noguchi T, Yanagihara K, Hirashita Y, Nakada C, Hijiya N, Uchida T, Matsuura K, Hamanaka R, et al: Expression of DDX27 contributes to colony-forming ability of gastric cancer cells and correlates with poor prognosis in gastric cancer. Am J Cancer Res 5: 2998-3014, 2015.

13. Buffart TE, Carvalho B, van Grieken NC, van Wieringen WN, Tijssen M, Kranenbarg EM, Verheul HM, Grabsch HI, Ylstra B van de Velde CJ and Meijer GA: Losses of chromosome $5 \mathrm{q}$ and $14 \mathrm{q}$ are associated with favorable clinical outcome of patients with gastric cancer. Oncologist 17: 653-662, 2012.

14. Lv X, Zhang L, Huang R and Song W: A clinical exploration of neoadjuvant chemotherapy with tegafur, gimeracil, and oteracil potassium capsules combined with oxaliplatin for advanced gastric cancer. Int J Clin Exp Med 8: 19030-19036, 2015.

15. Yolanda LV, Sergio PD, Hugo ES, Isabel AF, Rafael BZ, Aldo TD and Gonzalo CR: Gastric cancer progression associated with local humoral immune responses. BMC Cancer 15: 924, 2015.

16. Havranek O, Kleiblova P, Hojny J, Lhota F, Soucek P, Trneny M and Kleibl Z: Association of germline CHEK2 gene variants with risk and prognosis of non-Hodgkin lymphoma. PLoS One 10 e0140819, 2015

17. Havranek O, Spacek M, Hubacek P, Mocikova H, Markova J, Trneny M and Kleibl Z: Alterations of CHEK2 forkhead-associated domain increase the risk of Hodgkin lymphoma. Neoplasma 58 : 392-395, 2011.

18. Liu C, Wang QS and Wang YJ: The CHEK2 I157T variant and colorectal cancer susceptibility: A systematic review and meta-analysis. Asian Pac J Cancer Prev 13: 2051-2055, 2012.

19. Liu C, Wang Y, Wang QS and Wang YJ: The CHEK2 I157T variant and breast cancer susceptibility: A systematic review and meta-analysis. Asian Pac J Cancer Prev 13: 1355-1360, 2012.

20. Labonne JD, Chung MJ, Jones JR, Anand P, Wenzel W, Iacoboni D, Layman LC and Kim HG: Concomitant partial exon skipping by a unique missense mutation of RPS6KA3 causes Coffin-Lowry syndrome. Gene 575: 42-47, 2016.

21. Nishimoto HK, Ha K, Jones JR, Dwivedi A, Cho HM, Layman LC and Kim HG: The historical Coffin-Lowry syndrome family revisited: Identification of two novel mutations of RPS6KA3 in three male patients. Am J Med Genet A 164A: 2172-2179, 2014.

22. Borun P, Salanowski K, Godlewski D, Walkowiak J and Plawski A: Rapid detection method for the four most common CHEK 2 mutations based on melting profile analysis. Mol Diagn Ther 19: 419-425, 2015

23. Bak A, Janiszewska H, Junkiert-Czarnecka A, Heise M, PilarskaDeltow M, Laskowski R, Pasińska M and Haus O: A risk of breast cancer in women-carriers of constitutional CHEK2 gene mutations, originating from the North-Central Poland. Hered Cancer Clin Pract 12: 10, 2014.

24. Liu Y, Xu Y, Ouyang T, Li J, Wang T, Fan Z, Fan T, Lin B and Xie Y: Association between CHEK2 H371Y mutation and response to neoadjuvant chemotherapy in women with breast cancer. BMC Cancer 15: 194, 2015.

25. Abud J, Koehler-Santos P, Ashton-Prolla P and Prolla JC; Study Group on Hereditary Breast and Colorectal Cancer: CHEK2 1100DELC germline mutation: A frequency study in hereditary breast and colon cancer Brazilian families. Arq Gastroenterol 49: 273-278, 2012

26. Siolek M, Cybulski C, Gasior-Perczak D, Kowalik A, KozakKlonowska B, Kowalska A, Chłopek M, Kluźniak W Wokołorczyk D, Pałyga I, et al: CHEK2 mutations and the risk of papillary thyroid cancer. Int J Cancer 137: 548-552, 2015.

27. Ou TT, Wu CH, Hsu JD, Chyau CC, Lee HJ and Wang CJ: Paeonia lactiflora Pall inhibits bladder cancer growth involving phosphorylation of Chk2 in vitro and in vivo. J Ethnopharmacol 135: 162-172, 2011.
28. Teodorczyk U, Cybulski C, Wokołorczyk D, Jakubowska A, Starzyńska T, Lawniczak M, Domagała P, Ferenc K, Marlicz K, Banaszkiewicz Z, et al: The risk of gastric cancer in carriers of CHEK2 mutations. Fam Cancer 12: 473-478, 2013.

29. Sobin LH and Wittekind C (eds): International Union Against Cancer: TNM Classification of Malignant Tumors. 5th edition. Wiley-Liss, New York, 1997.

30. Livak KJ and Schmittgen TD: Analysis of relative gene expression data using real-time quantitative PCR and the 2(-Delta Delta C(T)) Method. Methods 25: 402-408, 2001.

31. Näslund-Koch C, Nordestgaard BG and Bojesen SE: Increased risk for other cancers in addition to breast cancer for CHEK2*1100delC heterozygotes estimated from the copenhagen general population study. J Clin Oncol 34: 1208-1216, 2016.

32. Wang Y, Dai B and Ye D: CHEK2 mutation and risk of prostate cancer: A systematic review and meta-analysis. Int J Clin Exp Med 8: 15708-15715, 2015.

33. Bayram S, Topaktas M, Akkiz H, Bekar A and Akgollu E CHEK2 1100delC, IVS2+1G $>$ A and I157T mutations are not present in colorectal cancer cases from Turkish population. Cancer Epidemiol 36: 453-457, 2012.

34. Francies FZ, Wainstein T, De Leeneer K, Cairns A, Murdoch M, Nietz S, Cubasch H, Poppe B, Van Maerken T, Crombez B, et al: BRCA1, BRCA2 and PALB2 mutations and CHEK2 c.1100delC in different South African ethnic groups diagnosed with premenopausal and/or triple negative breast cancer. BMC Cancer 15: 912, 2015.

35. Maddaly R, Sahu B and Mohan DK: Genes associated with human cancers: Their expressions, features, functions, and significance. Crit Rev Eukaryot Gene Expr 25: 209-238, 2015.

36. Pohlreich P, Kleibl Z, Kleiblová P, Janatová M, Soukupová J, Macháčková E, Házová J, Vašíčková P, St’ahlová Hrabincová E, Navrátilová M, et al: The clinical importance of a genetic analysis of moderate-risk cancer susceptibility genes in breast and other cancer patients from the Czech Republic. Klin Onkol 25 (Suppl): S59-S66, 2012 (In Czech).

37. Massink MP, Kooi IE, Martens JW, Waisfisz Q and MeijersHeijboer H: Genomic profiling of CHEK2*1100delC-mutated breast carcinomas. BMC Cancer 15: 877, 2015

38. Ollier M, Radosevic-Robin N, Kwiatkowski F, Ponelle F, Viala S, Privat M, Uhrhammer N, Bernard-Gallon D, Penault-Llorca F, Bignon YJ and Bidet Y: DNA repair genes implicated in triple negative familial non-BRCA1/2 breast cancer predisposition. Am J Cancer Res 5: 2113-2126, 2015.

39. Davari K, Frankenberger S, Schmidt A, Tomi NS and Jungnickel B: Checkpoint kinase 2 is required for efficient immunoglobulin diversification. Cell Cycle 13: 3659-3669, 2014.

40. Stolz A, Ertych N and Bastians H: Tumor suppressor CHK2: Regulator of DNA damage response and mediator of chromosomal stability. Clin Cancer Res 17: 401-405, 2011

41. Bakhoum SF, Kabeche L, Murnane JP,Zaki BI and Compton DA: DNA-damage response during mitosis induces whole-chromosome missegregation. Cancer Discov 4: 1281-1289, 2014.

42. Liang W, Lai Y, Zhu M, Huang S, Feng W and Gu X: Combretastatin $\mathrm{A} 4$ regulates proliferation, migration, invasion and apoptosis of thyroid cancer cells via PI3K/Akt signaling pathway. Med Sci Monit 22: 4911-4917, 2016.

43. Voutsadakis IA: Epithelial-mesenchymal transition (emt) and regulation of emt factors by steroid nuclear receptors in breast cancer: A review and in silico investigation. J Clin Med 5: pii: E11, 2016. 